\title{
Management of Community Development Activities Among Parent-Teacher Association Stakeholders in Area V, Leyte Division, Philippines
}

\author{
Roland A. Niez ${ }^{1 *}$, Cristeta Jordan ${ }^{2}$, Concepcion M. Gayrama ${ }^{3}$, \\ Noel Felimon Gayrama \\ Naval State University, Naval, Biliran 6560 Philippines
}

\begin{abstract}
The study aimed to determine the management of community development activities among the Parent-Teacher-Association stakeholders in Area v, Leyte Division. Utilizing the quantitative research design, the study employed survey questionnaire as the main data gathering tool through the 200 respondents composed of teachers and parents. Results indicate that the profile of the respondents did not affect, in any way, the management of the Parent-Teacher-Association stakeholders. In the core management functions, the PTA stakeholders were found to have highly practiced in leading; whereas, planning, organizing and controlling were found to be on "practice" level. Lack of fund and inadequate skills and improper management of the PTA stakeholders came out as the main issue and concern. Similar studies maybe conducted but will examine other aspects and nature of variables on management skills and capabilities vis-à-vis community development related activities to come up with genuine and adequate data as basis for other future research into this subject.
\end{abstract}

Keywords: management; community development; community participation parent-teacher association.

\section{Introduction}

Over the past 50 years, the notion and nature of parent or family involvement has transformed from a narrowly defined concept into a wider set of ideas and goals. In other words, it does not only limit to participation in parent organizations (i.e. parent associations and parent-teacher associations), which often includes activities that are unidirectional (parents give to schools) with involvement that is exclusive or practiced only by a small group of privileged parents and with a narrow focus centering solely on their children's achievement, but also expands to the development of mutual partnerships involving a range of families and community members and groups (Glasgow \& Whitney, 2009, p. 2). Having said that, people are beginning to recognize a new range of family involvement. With a view to knowing more of the nowadays work of the PTA, it is worth noting, in its broadest sense, other nature and aspects of parent involvement, which has been unostentatiously taken up by the PTA.

Parent teacher Association is a democratic organization which attempts to bring parents and teachers together in the interest of the child (Ajayi, 1999). It is a formal link of communication on school matters between the teachers and parents. According to Oniyangi (2008), the meeting of this body serves as a forum for the exchange of ideas between teachers and parents about school programs towards the smooth running of the school and the achievements of the goals of the school.

The importance of engaging communities in addressing barriers to education has come to the forefront as governments worldwide strive to reach their commitments to Education for All goals by 2015. Governments are increasingly recognizing the value of working with communities and sharing responsibility for, and ownership of, educational systems.

Community participation is a generalized term that is used to reflect a gamut of levels of involvement with communities. The World Health Organization (WHO) characterizes community participation on three levels: marginal, substantive, and structural. In marginal participation, community input is "limited and transitory and has little direct influence on the outcome of the development activity." Substantive participation is characterized by the community being actively involved in determining priorities and carrying out activities, even though the mechanisms for these activities may be controlled externally. In structural participation, the community is involved as an integral part of the project, and its participation becomes the ideological basis for the project itself. In this last case, the community plays an active and direct part in all aspects of the development process and has the power to ensure that its opinions are taken into account (SullivanOwomoyela\&Brannelly, 2009).

The Inter-Agency Network for Education in Emergencies (INEE) defines community participation as including both the processes and the activities that allow members of an affected population to be heard, empower them to be part of decision-making processes, and enable them to take direct action on education 
issues. It uses symbolic/token participation, consultation, and full participation to identify the different levels (INEE, 2004).

Porter (2008) elaborates that parent involvement can take place at home through providing active help with children's schoolwork, parents keeping informed 34 of what is happening for their children at school, monitoring their academic progress, reading to their children and providing intellectually stimulating activities for them.Porter further elaborates that a more visible form of parent involvement is direct involvement at school through parents participating in parent-teacher meetings, being an audience at their children's school performances, assisting in the classroom, collaborating with teachers to make educational decisions for their children, volunteering on fundraising activities, or even contributing to development of school policies as one of the members in the school council.

In addition, apart from indirect support and involvement at home as well as direct engagement at school, Porter (2008a) adds that parent involvement may be originated from parents' values, beliefs and aspirations .

Parents' values, beliefs and aspirations about education elucidate the rationale behind their involvement, while the remaining two dimensions illustrate the form of their involvement (Fan, 2001). It is suggested that these three dimensions are quite unique on their own, and have different effects on children's educational outcomes (Fan, 2001; Keith et al., 1998).

While much has been said about the illustrious support and direct involvement of the parents and the community to the school with the aim of extending support to the educational goal for their children, the schools in Area V in Leyte Division is also an institution where there is a need to study the situation between the schools in this area and the PTA to find out the extent of their association towards their mutual goal for academic development. Since there is only a dearth of studies conducted in this locale and in the Philippines in general, the researcher is mainly interested in looking at this subject. Hence, the study was undertaken.

\subsection{Objectives of the Study}

The study generally intended to look at the management of community development activities of the Parent-Teacher-Association in Area V, Leyte Division, Philippines. Specifically, this sought answers to the following: 1.) find out the profile of the parent-teacher association stakeholders in terms of age, sex, civil status, educational attainment, average monthly income, number of dependents, occupation of parents and position of teachers; 2.) identify the community development activities of the parent-teacher association for the last three (3) years; 3.) describe the management practices of community development activities in terms of planning, organizing, leading and controlling; 4.) identify the issues and concerns in the management of community development activities; 5.) evolve a five (5) year plan on the implementation of community development activities.

\subsection{Framework of the Study}

This section presents the theoretical and conceptual frameworks of the study.

Theoretical framework. The study is anchored on theories that give meaning and purpose to the basic considerations of the research.These are Human Resource Theory, Expectancy-Value Theory and Human Capital Theory.

Miles (2000) on Human Resource Theory views individuals as organizational resources for defining and solving problems as capable, responsible, self-directed and ultimate self-controlled members of the organization. Human Resource Theory informs those thinking around management that exists when implementing a high-stake accountability process such as individual evaluation.

In support and in view of Expectancy theories of Atkinson (1957) and Feather (1982), they assume that human behavior is a joint function of people's expectations that a particular behavior will bring certain outcomes and the value of those outcomes clearly if an educational outcome is thought to be unattainable or worthless, individuals will not be motivated.

Equally parallel in nature is the Human Capital Theory espoused by Schultz, Sakatoma and Powers. This theory rests on the assumption that management of an organization is highly instrumental and even necessary to improve the production capacity of a population. In short, the human capital theorists argue that skilled managers make up productive population. Human capital theory emphasizes how education increases the productivity and efficiency of workers by increasing the level of cognitive stock of economically productive human capability which is a product of innate abilities and investment in human capital, which the proponents of the theory have considered as equally or even more equally worthwhile than that of physical capital.

Conceptual framework. The concept of this study is premised on determining the management of community development activities among the Parent-Teacher-Association in Area V, Leyte District. The first variable as reflected in the first box is the socio-demographic profile of the parent and teacher respondents which include: age, sex, civil status, educational attainment, average monthly income, number of dependents, 
and occupation of parent and position of teacher.Another variable to be looked into which is contained in the second box is on the community development activities of the Parent-Teacher-Association for the last three years.In like manner, in the third box is the management practices of community development activities in terms of planning, organizing, leading and controlling. The fourth box concerns on the issues and concerns that arise in the management of community development activities.Finally, the last box, which is the main output of the study, is the production of a five-year development plan designed to improve the management of community development activities among the Parent-Teacher-Association in Area V, Leyte Division.

The illustration of the conceptual framework is presented in Figure 1

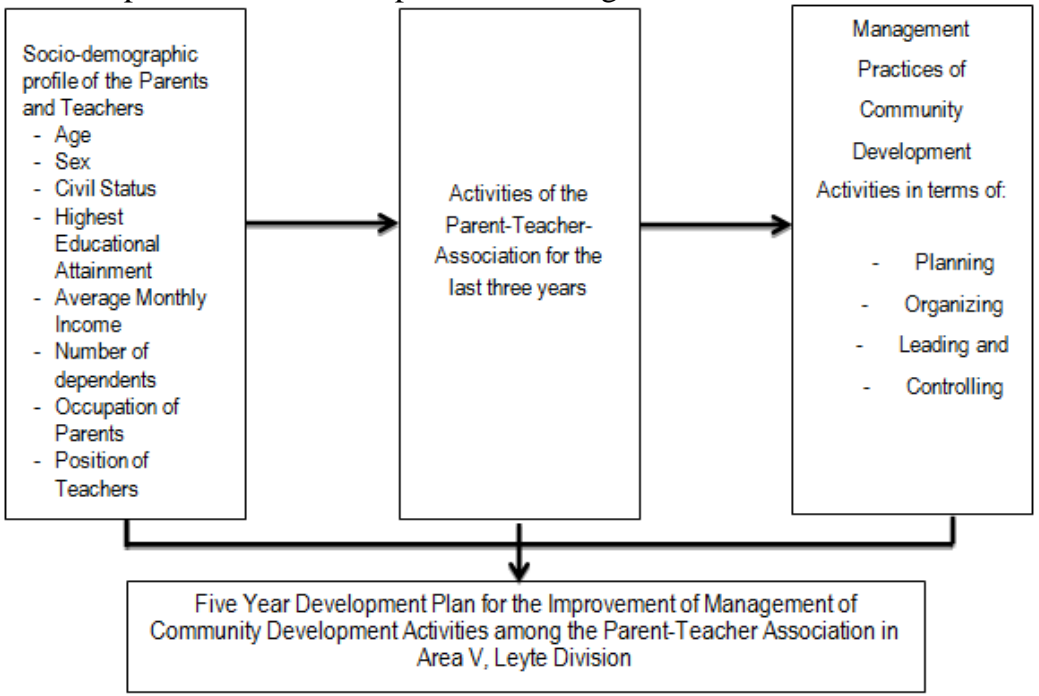

Figure 1: The Conceptual Framework of the Study

\subsection{Scope and Delimitation of the Study}

This study is limited only to the assessment of the management of community development activities of the Parent-Teacher Association stakeholders in Area V, Leyte Division. Only the parents and teachers were utilized as respondents of the study where a total of 200 participants were taken.

\subsection{Review of Literature}

Parent teacher Association is a democratic organization which attempts to bring parents and teachers together in the interest of the child (Ajayi, 1999). It is a formal link of communication on school matters between the teachers and parents. According to Oniyangi (2008), the meeting of this body serves as a forum for the exchange of ideas between teachers and parents about school programs towards the smooth running of the school and the achievements of the goals of the school.

The importance of engaging communities in addressing barriers to education has come to the forefront as governments worldwide strive to reach their commitments to Education for All goals by 2015. Governments are increasingly recognizing the value of working with communities and sharing responsibility for, and ownership of, educational systems.

Community participation is a generalized term that is used to reflect a gamut of levels of involvement with communities. The World Health Organization (WHO) characterizes community participation on three levels: marginal, substantive, and structural. In marginal participation, community input is "limited and transitory and has little direct influence on the outcome of the development activity." Substantive participation is characterized by the community being actively involved in determining priorities and carrying out activities, even though the mechanisms for these activities may be controlled externally. In structural participation, the community is involved as an integral part of the project, and its participation becomes the ideological basis for the project itself. In this last case, the community plays an active and direct part in all aspects of the development process and has the power to ensure that its opinions are taken into account (Sullivan-Owomoyela \& Brannelly, 2009).

The Inter-Agency Network for Education in Emergencies (INEE) defines community participation as including both the processes and the activities that allow members of an affected population to be heard, empower them to be part of decision-making processes, and enable them to take direct action on education issues. It uses symbolic/token participation, consultation, and full participation to identify the different levels (INEE, 2004). 
Establishing and maintaining trust is the foundation for all productive, mutually beneficial relationships. The importance of establishing trust applies to all parties engaged in the school environment, including trust between external parties and the community and between community representatives and community members at large. Trust is engendered when there is demonstrated credibility and transparency in all stages of the development of the relationship. Credibility is best established through clear communication, regular consultation, and reliable follow-through. With these in place, community members gain confidence that they will be dealt with honestly and can reasonably depend on the authenticity of what they are being told. Establishing the credibility of all partners in this way is essential to maintaining motivation and involvement among participants. Conversely, a lack of credibility, particularly a lack of follow-through on agreements made, is a common reason for participation to drop off abruptly. Transparency includes being open about intentions and motivations as well as processes and resources. An extensive review of the literature on trust identified five common factors of trust: benevolence (the intent to see the issue and possible solutions from the point of view of the community), reliability, competence, predictability (honesty), and transparency (Randell, n.d.).

Shaeffer (1994), in a review of community participation initiatives, writes more specifically: The important thing in all of this process is to ensure transparency and clarity. This requires clear, but flexible guidelines, rules, and frameworks for collaboration and participation; open dialogue, frank feedback, and clear channels of communication and information transfer among the participants; and, for each of the participants, clearly defined (and written) policies, guidelines, and parameters regarding tasks and functions, rights and responsibilities, limitations and resources, and procedures and formats for reporting and accounting.

Transparency was one of the sustaining factors consistently identified by local committees working on OVC awareness in Zambia and Malawi. They felt that this was closely related to level of participation, and many committee members felt that this factor strengthened their unity as a committee. In fact, community support encouraged transparency on the part of the committees, and a perceived lack of transparency often undermined the work of the committees (Donahue \& Mwewa, 2006). The importance of establishing mechanisms to ensure absolute transparency is multiplied when financial or other material resources are an element of the engagement.

Staff of the New Schools Project (NSP) in Egypt found that trust developed through concrete actions and was fostered when community members saw that their ideas and concerns had not only been listened to, but acted upon. Originally distrustful of the initiative, parents significantly increased their support for the idea of multigrade community schools when they saw that the design of the schools reflected their concerns about the conditions through which their daughters were enrolled in education, such as proximity to the home, single-sex classes, female teachers, and the ability to attend school without neglecting household chores (AIR, 2008).

In an analysis of the effectiveness of community schools for girls' education, one of the significant factors identified was the importance of ensuring consensus among key constituents in the community around establishing a school. The choice should be a conscious act of self-selection whereby mutual respect and an equal relationship are established and communities select the program as much as the program selects the communities (Hartwell, 1998.).

In early 1997, CARE's rural rehabilitation project in Afghanistan carried out participatory rural assessments in communities where it was working. Twenty of the 38 communities ranked education as one of their top three priorities. The COPE community schools were thus established in partnership with the communities as a response to a community-identified priority. A project evaluation credits this process with the degree to which many communities have taken responsibility for their schools. For example, during the Taliban rule, some communities were cut off for a time, but many of the schools continued to operate, particularly when they had the support of local religious leaders. In such cases, the classes maintained their identity as local rather than foreign donor-supported initiatives (Chabbott, 2006).

The most successful partnerships include community members' leadership and participation in all aspects of the initiative: assessment, planning, implementation, monitoring, and evaluation. Community members in Malawi linked full ownership of the process with avoiding fraud: As one community member put it, "There must be a strong partnership between leaders and community members. Everyone should see how and to whom resources are distributed. Monitoring must be done by the local leaders and cross-checked by donors, while clearly putting most of accountability on the local leaders. Donors should avoid the impression that they are driving the process of decision-making at the community level.” (Donahue \& Mwewa, 2006).

In an inclusive partnership, the partners actively seek to involve all groups in the community, with a particular emphasis on the inclusion of women and other marginalized groups, such as ethnic or religious minorities, refugees, or those living with HIV/ AIDS. Although any education initiative naturally seeks to involve parents, other community members are sometimes forgotten. Community members who are not necessarily parents (e.g., religious leaders, youth, private-sector representatives) can be beneficially engaged in education efforts. Genuine inclusion and participation provide substantive, meaningful opportunities that are not merely representational. This type of inclusion not only increases support for the educational initiative but also 
can have an impact on the environment in which children live, often transforming attitudes about schooling and opportunities for previously excluded groups. However, inclusive participation is often more difficult than it first appears. Many attempts to include women, particularly in places where they have been traditionally excluded, have failed to address the conditions that prevent women from participating. A study of community participation in education and gender relations in Sub-Saharan Africa found that attempts were made to include women as members of school committees in a number of countries. Often, however, conditions were not addressed to ensure that women felt free to speak out on these committees or that their opinions were considered in decisions being made. Meetings were often held at times women could not attend because of household commitments (Rose, 2003).

A review conducted by Catholic Relief Services of its work in several countries concluded that having a long-term presence in and commitment to countries and communities facilitates a gradual shift from communities' participation in specific projects to their taking a more-central role in supporting education. Mutual trust and the relationships that develop and take root during this time build the foundation for strong, effective partnerships (Carneal \& Pozniak, 2004).

Engaging with communities in crisis situations may require greater effort initially because they are often in a state of flux or trauma and are unable or unwilling to give time to anything beyond basic survival needs. However, the strong desire to reestablish normalcy may also make communities more willing than usual to assist in education initiatives (Sullivan-Owomoyela \& Brannelly, 2009). The principle of "Do no harm" is also important when engaging with communities in an exploratory process, particularly one that seeks to draw out traditionally excluded groups. Opening avenues for the expression of criticism or frustration without providing ways for people of divergent perspectives to work together to address their concerns can leave people vulnerable to repercussions within the community. Engaging the expertise of partners who have experience in participatory assessments in both selecting tools and conducting the assessment is advisable.

The overall findings of the community analysis must be made available to all. In Zambia and Malawi, for example, sharing the results of the participatory analysis with the community stimulated a sense of ownership of problems and action beyond the leadership and committee members to the wider community (Donahue \& Mwewa, 2006).

The findings should be presented in various formats that are accessible to all members of the community, including those who are not literate. The methods can include presenting them orally and preparing visual posters and displays. The arts Education already has a formally recognized community level mechanism, it should be engaged and strengthened. Wider, formal alliances may be more effective for targeting broader community-wide concerns, which may be a specific issue, such as child labor or the needs of orphans and vulnerable children, or oversight of several education programs in one area. One model of such an alliance is a community education committee, which is representative of all the groups in the community and may include school administrators, teachers, and staff; parents or caregivers; children and youth; civil society organizations; religious organizations; traditional leaders; and health workers (INEE, 2003). Examples are SAGE local alliances in Guinea, which involved a broad range of organizations and agencies (including PTAs); community, religious, and business leaders; women's associations; and other interested parties (Shumann, n.d.).

Where an existing structure is in place and holds community confidence, it is most appropriate to work within that structure. In some cases, however, existing structures are ineffective or reinforce entrenched power dynamics in communities. If the community is amenable, an existing body can be restructured to better reflect the makeup of the community. For example, a PTA that was previously appointed can be democratically elected. Where resistance to changing an existing albeit ineffective format is strong, an alternative structure may be established. This was the case with the local alliances, which were more effective than the PTA alone had been. Regardless of the specific structure used, criteria should be adopted to ensure that its members are representative of the makeup of the community, including women and other traditionally excluded groups. The successful School for Life Committees in Ghana, for example, have five members and specify that there must be three women and two men, one of whom is usually a representative of the chief, the local assembly, or the women's organization (Hartwell, 2006).

In the PACEEQ program, the literacy component was shown to be an effective source of motivation and inspiration for parent association members that went beyond the acquisition of basic literacy skills. Learners reported increased self-esteem after participating in the literacy program, and women who participated were more likely to be active members of the parent association (World Education Guinea, 2007). Care must be taken to ensure that training sessions not only are open to underrepresented groups but also are accessible. Schedules should be set to maximize participation and not be held during prime working time for women, farmers, and other groups, thus excluding them by default. Capacity development takes different forms, such as formal training, experiential learning gained from participation in processes, and mentoring. A variety of methods should be employed to ensure that training is as interactive as possible. Methods such as role plays, simulation games, and practical exercises, including preparing meeting agendas and minutes, making a budget, and 
facilitating a meeting, often help participants quickly internalize new skills. COPE trainers in Afghanistan used a combination of lecture, brainstorming, group work, problem solving, storytelling, and field trips (Chabbott, 2006). An activity used in PACEEQ trainings asks participants to make an illustrated daily calendar in which they "map" how boys and girls spend their time. Faced with a visual reality, participants draw their own conclusions about how the unequal distribution of household chores can have a negative impact on girls' education and what practical steps can be taken to ensure that girls have adequate time to devote to school (World Education Guinea, 2007). Exchange visits with other communities engaged in similar education initiatives were also found to be effective in some settings.

Despite its' importance, parental involvement is generally believed to be discouragingly low (Davies, 2002; Gonzalez-DeHass \& Willems, 2003; Mapp, 2003). However, there are limited empirical studies to support this belief. One survey of 51 elementary parents showed that only $30 \%$ of the parents volunteered in the classroom or helped with fund-raising activities (Becker \& Epstein, 1982). In a second study, 30\% of 1,269 elementary parents volunteered at school or helped with fund-raisers, and $65 \%$ of elementary parents attended parent-teacher conferences (Epstein, 1986). Parent-teacher conferences have been found to be the most common means of involving parents (Shores, 1998). The Harvard Family Research Project found that parent-teacher conferences were the most frequently cited family involvement activity (Shartrand, Kreider, \& EricksonWarfield, 1994).

A different survey, with 341 teachers of 1,205 kindergarten through third-grade students, showed that $41 \%$ of the parents attended Parent-Teacher Organization meetings and $48 \%$ attended school activities, such as plays and bake sales (Izzo, Weissberg, Kasprow, \& Fendrich, 1999). Additionally, 53\% of these parents participated in activities at home to foster their children's academic development, and $49 \%$ participated in activities at home to foster their children's social skills. The National Center for Education Statistics gathered information regarding rates of parental involvement via telephone interviews with parents of 9,700 children in kindergarten through eighth grade (Chen \& Chandler, 2001). Results showed that $84 \%$ of parents attended an open house or back-to-school night and $81 \%$ attended parent-teacher conferences.

More recent studies have shown that the rate of parental involvement is particularly low with economically disadvantaged, ethnic minority, and less-educated families (Dauber \& Epstein, 1993; Dornbusch \& Ritter, 1988; Griffith, 1996; Ho, 2002; Moles, 1993). Single mothers and parents with lower socioeconomic status (SES) are significantly less involved in school activities and home activities than married parents and those with higher SES (Grolnick, Benjet, Kurowski, \& Apostoleris, 1997). They go to fewer school events, go to the library less, talk with teachers less, and talk about current events with their children less than married parents and parents with higher SES. White parents reported more frequent involvement at school and at home than parents of Hispanic, Asian, Black, Pacific Islander, and Native American ethnicity (Griffith; Ho). White parents talked to teachers more, ensured homework was completed, listened to their child read, and communicated more with the school than parents of other ethnicities (Ho). Parents who had completed high school or beyond were more involved in their children's education than parents who did not complete high school (Dauber \& Epstein).

Researchers have grouped school and home activities of parental involvement into different dimensions (Epstein, 1995; Grolnick \& Slowiaczek, 1994). Behavioral, cognitive-intellectual, and personal are three dimensions representing resources that parents have available to children (Grolnick \& Slowiaczek). The atschool and at-home activities of 'volunteering' and 'helping with homework' are behavioral resources. Exposing the child to cognitively stimulating activities, such as going to the library or talking about current events, are cognitive-intellectual resources. Personal resources include parents' affective involvement reflected in his or her positive attitude, caring, and expectations toward school and learning. Parental involvement activities have also been represented as existing along a single continuum that extends from home-based activities to school-based activities and finally to home-school collaboration (Shores, 1998). At one end of the continuum are athome activities, such as reviewing report cards, ensuring school attendance, and monitoring homework. Called "limited capacity for involvement" (p. 13), Shores implies that some parents do not have the ability, resources, or time for more involvement, and that these activities are not as important for child success. In the middle are traditional at-school activities, such as attending parent-teacher conferences and volunteering. At the other end are more collaborative at-school activities, such as planning classroom activities with teachers and participating in policy making activities. These activities give parents more power and influence over how the school is run.

\section{Methodology}

The descriptive-survey method was adopted with the survey questionnaire as the main data gathering tool. This design is appropriate to the study since it only describes the various data generated concerning the management skills and abilities of the Parent-Teacher-Association stakeholders that manage community development activities in the target area. 
The study was conducted in Area V, Leyte Division in the Philippines, particularly in Javier, Abuyog and Mahaplag municipalities where the twenty-five(25) elementary schools were taken.

A total of 200 respondents composed of the parents and teachers of the PTA association were tapped as respondents. The selection and sampling of the respondents was made according to their availability at the time the researcher had visited their schools and conducted the survey.

The research tool is self-made with some concepts lifted from the unpublished thesis in July 2006 of Ms. Helen Salvestrin of the University of Technology, Sydney. Contained in the questionnaire are the following: Part I includes questions designed to collect demographic information such as age, sex, civil status, educational attainment, average monthly income, number of dependents, and occupation of parents and position of teachers. Part II is intended to identify the community development activities of the Parent-TeacherAssociation for the last three years.Part III yields information on the management practices of community development activities in the four areas of management: planning, organizing, leading and controlling.Part IV provides the issues and concerns that arise in the management of community development activities. The Pearson Product Moment correlation was applied as statistical tool.To measure the management practices, simple percentage and the weighted mean were utilized.

\subsection{Profile of the Respondents}

\section{Results and Discussion}

This section shows the profile of the respondents in terms of: age, sex, civil status, educational attainment, average monthly income, number of dependents, and occupation of parents and position of teachers. This is presented in the succeeding tables.

Table 1:Profile of the Respondents

\begin{tabular}{|c|c|c|}
\hline Variables & f & $\%$ \\
\hline \multicolumn{3}{|l|}{ Age } \\
\hline 60 and above (Senior Citizen) & 1 & 0.5 \\
\hline $46-59(\mathrm{Old})$ & 103 & 51.5 \\
\hline 22-45 (Middle Age) & 96 & 48.0 \\
\hline 21 and below (Young) & 0 & 0 \\
\hline Total & 200 & 100 \\
\hline \multicolumn{3}{|l|}{ Sex } \\
\hline Male & 74 & 37.0 \\
\hline Female & 126 & 63.0 \\
\hline Total & 200 & 100 \\
\hline \multicolumn{3}{|l|}{ Civil Status } \\
\hline Single & 7 & 3.5 \\
\hline Married & 193 & 96.5 \\
\hline Total & 200 & 100 \\
\hline Doctorate Degree Holder & 2 & 1.0 \\
\hline Masteral Degree Holder & 36 & 18.0 \\
\hline College Graduate & 72 & 36.0 \\
\hline College Level & 36 & 18.0 \\
\hline HS Graduate & 18 & 9.0 \\
\hline HS Level & 26 & 13.0 \\
\hline Elementary Graduate & 10 & 5.0 \\
\hline Total & 200 & 100 \\
\hline \multicolumn{3}{|l|}{ Average Monthly Income } \\
\hline 30,000 and above & 114 & 57.0 \\
\hline $20,000-29,000$ & 40 & 20.0 \\
\hline $10,000-19,000$ & 36 & 18.0 \\
\hline Below 10, 000 & 10 & 5.0 \\
\hline Total & 200 & 100 \\
\hline \multicolumn{3}{|l|}{ Number of Dependents } \\
\hline none & 72 & 36.0 \\
\hline $1-2$ & 52 & 26.0 \\
\hline $3-4$ & 49 & 24.5 \\
\hline $5-6$ & 11 & 5.5 \\
\hline $7-8$ & 16 & 8.0 \\
\hline Total & 200 & 100 \\
\hline \multicolumn{3}{|l|}{ Occupation of Parents } \\
\hline Lawyer & 2 & 2.0 \\
\hline Municipal Officials & 2 & 2.0 \\
\hline Policeman & 3 & 3.0 \\
\hline Businessman or Store Owner & 53 & 53.0 \\
\hline Clerk & 6 & 6.0 \\
\hline Nurse & 4 & 4.0 \\
\hline Engineer & 3 & 3.0 \\
\hline Barangay Officials & 23 & 23.0 \\
\hline
\end{tabular}




\begin{tabular}{|l|l|l|}
\hline Farmer & 6 & 6.0 \\
\hline Total & $\mathbf{2 0 0}$ & $\mathbf{1 0 0}$ \\
\hline Position & & \\
Master Teacher II & 38 & 38.0 \\
Master Teacher I & 32 & 32.0 \\
Teacher III & 10 & 10.0 \\
Teacher II & 3 & 3.0 \\
Teacher I & 15 & 15.0 \\
\hline Total & $\mathbf{1 0 0}$ & $\mathbf{1 0 0}$ \\
\hline & & \\
\hline
\end{tabular}

It can be seen that, as to the age of respondents, majority of them or 51.5 percent with a frequency of 103 are old. This is closely followed by middle age at 48 percent with a frequency of 96 while the rest of 0.5 percent with a frequency of 1 is senior. The data clearly shows that a greater number of the respondents are already old.

As regard the respondents' sex, more than one-half or 63 percent with a frequency of 126 are female and the other 37 percent with a frequency of 74 are male. This marks that many of the school heads and parentteacher association presidents are female. An implication draws that female is equally qualified and competent as the male when it comes to leadership.

For civil status, more than three-fourths or 96.5 percent with a frequency of 193 are married while the remaining 3.5 percent with a frequency of 7 is single. This is expected since PTCA organization is composed of members who are mostly parents and married individuals.

When it comes to educational attainment of the respondents, a bigger number with 36 percent or a frequency of 72 were college graduates. Next are those who were college levels and with masters' degrees at 18 percent each with frequencies of 36 for both. The least portions were those with doctorate degrees and elementary graduates at 1 percent and 5 percent with frequencies of 2 and 10 respectively. This goes to show that the school heads still have greater room for academic growth to eventually become self-actualized by obtaining doctorate degrees. On the other hand, becoming PTCA President is not solely based on the academic background or qualifications as evidenced by some with lower academic rank holding the position.

In terms of average monthly income, more than half of the respondents or 57 percent with a frequency of 114 were at P30,000 and above. The least is at 5 percent with a frequency of 10 with an income of below $\mathrm{P} 10,000$. The data indicates that the respondents have varied average monthly income although half of them is on the highest range.

Regarding the number of dependents, the highest number of the respondents or 72 of them were without dependents. This is followed by 52, 49, 11 and 16 with 1-2,3-4,5-6 and 7-8 dependents respectively. This means that there is financial sufficiency with many of the respondents given the number of dependents that they have.

As to occupation of parents, more than half of the respondents or 53 percent were businessmen or store owners. This is followed by barangay officials with a frequency of 23 or 23 percent. The least are the municipal officials and lawyers with frequencies of two each or two percent. The data shows that the highest number of respondents are into business. This finding suggests that members of the PTA association have varied occupations.

On position of teachers, the greater number of the respondents with a frequency of 38 or 38 percent occupied Master Teacher II position. Next in rank is Master Teacher I with a frequency of 32 or 32 percent. Ranked last is Teacher I with a frequency of 3 or 3 percent. The data discloses that many of the respondents occupy the highest position (Master Teacher II). Finding likely implies that the teachers prioritize their academic advancement which is reflective of their present position achieved.

3.2 Community Development Activities of the Parent-Teacher Association for the last three (3) years

Table 2: Community Development Activities of the Parent-Teacher Association for the last Three (3) Years

\begin{tabular}{|l|l|l|}
\hline Activities & f & Rank \\
\hline Garbage Waste Disposal & 198 & 1 \\
\hline Organize Livelihood Projects & & \\
School/Community Vegetable Gardening/Production & 186 & 5.5 \\
Garbage Recycling & 179 & 10.5 \\
Backyard Poultry/Piggery/Animal Production & 112 & 23 \\
Food Preservation & 78 & 25 \\
Craftsmanship & & \\
\hline Sustaining and Safeguarding the Environment & 189 & 4 \\
Tree Planting/Reforestation/Illegal Fishing & 196 & 2 \\
\hline Cleanliness and Beautification & 194 & 3 \\
\hline Health and Sanitation & & \\
\hline Service Partners of NGO & 136 & 21.5 \\
\hline Sagip Kapamilya ABS-CBN & & \\
\hline
\end{tabular}


Management of Community Development Activities Among Parent-Teacher Association ......

\section{*Multiple Response}

\begin{tabular}{|l|l|l|}
\hline Red Cross Philippines & 142 & 19 \\
Habitat for Humanity & 139 & 20 \\
Save the children & 147 & 18 \\
Samaritan's Purse & 163 & 14 \\
Tzu Chi Foundation & 172 & 12 \\
UNICEF & 183 & 7.5 \\
Gawad Kalinga & 160 & 7.5 \\
\hline Fiesta Celebration Activities & 161 & 15 \\
\hline Yuletide Season Activities & 158 & 17 \\
\hline Barangay/Town Special Celebrations/Commensuration/Anniversary Activities & 179 & 10.5 \\
\hline Fund Raising Activities of the School/Church & 183 & 7.5 \\
\hline Family Mapping Activities & 136 & 21.5 \\
\hline Construction of Reading Centers in the Barangay/Purok & 79 & 24 \\
\hline Lenten Season Activities & 169 & 13 \\
\hline Service Learning Program(Catechism, Values Educ.etc) & 181 & 9 \\
\hline Distribution of Relief Goods during/after calamities & 186 & 5.5 \\
\hline
\end{tabular}

As viewed in the table on community development activities of the PTA stakeholders for the last three years, out of the 21 activities, garbage waste disposal topped the rank; second is cleanliness and beautification, third is health and sanitation and last is craftsmanship.

Generally, in the classification, the garbage waste disposal came out to be the top priority project; sustaining and safeguarding the environment ranked second and service partners of NGO ranked last. The data simply connotes that cleanliness and orderliness is being valued highly by the PTA stakeholders. Likewise, this would imply that much of the efforts are placed on simple and ordinary activity.

\subsection{Management Practices of Community Development Activities}

The management practices of community development activities were assessed in terms of planning, organizing, leading, and controlling.

Table 3: Management Practices of Community Development Activities in terms of Planning

\begin{tabular}{|c|c|c|}
\hline Planning & WM & Description \\
\hline Develop long range program & 3.78 & Highly Practiced \\
\hline Establish program objectives & 3.87 & Highly Practiced \\
\hline Formulate written program policies & 3.15 & Practiced \\
\hline Prepare the program budget & 3.0 & Practiced \\
\hline Has written up all our main activities into a calendar. & 2.71 & Practiced \\
\hline Has broken down all activities into the specific tasks needed to do to achieve. & 4.14 & Highly Practiced \\
\hline Knows what their role and responsibility is. & 4.37 & Very Highly Practiced \\
\hline Has regular reporting guidelines. & 4.21 & Highly Practiced \\
\hline $\begin{array}{l}\text { Has regular meetings to check on the project progress and plan for the coming } \\
\text { activities. }\end{array}$ & 3.54 & Highly Practiced \\
\hline There is a good, clear communication system in place. & 3.42 & Practiced \\
\hline Checking of the aims and objectives are being achieved. & 3.08 & Practiced \\
\hline Has written up a final report (narrative and financial) & 3.47 & Practiced \\
\hline Has reported to the stakeholders & 2.98 & Practiced \\
\hline Initiates ideas about community development activity. & 3.41 & Practiced \\
\hline Study potential activity related to community development. & 3.22 & Practiced \\
\hline Plans for implementation of a community development activity & 2.55 & Slightly Practiced \\
\hline Considers rules and regulations in the implementation of the activity. & 2.71 & Practiced \\
\hline Identifies and locates community members . & 3.56 & Practiced \\
\hline Facilitates in bringing individuals together . & 3.19 & Practiced \\
\hline Classifies and stores knowledge & 3.41 & Practiced \\
\hline Accesses and contributes to the knowledge . & 2.84 & Practiced \\
\hline Broadcasts the existence and purpose of the community & 2.39 & Slightly Practiced \\
\hline Plans regular face-to-face meetings between the members . & 3.66 & Highly Practiced \\
\hline Harvests/creates new knowledge from experience and external sources · & 3.62 & Highly Practiced \\
\hline AWM & 3.34 & Practiced \\
\hline
\end{tabular}

As provided in the table, the management practices of community development activities in terms of planning reveal an average weighted mean of 3.34 marked as practiced. Out of 28 indicators, the indicator "knows what their role and responsibility is" obtained the highest weighted mean of 4.37 interpreted as very highly practiced. Five indicators were noted as highly practiced and majority were practiced. Only two indicators "plans for implementation of a community development activity" and "broadcasts the existence and purpose of the community" were found to be slightly practiced. The data signifies that the respondents strongly assume their responsibilities and tasks as part of their management practices for community development 
activities. However, for planning to be effective, there is a need for them to seriously take improve planning efforts and also make known the presence and importance of any community development activities being introduced and implemented. Likewise, information drive about any community development activity should be considered in the plan.

Table 4: Management Practices of Community Development Activities in terms of Organizing

\begin{tabular}{|l|l|l|}
\hline Organizing & WM & Description \\
\hline Organizes user-training sessions and helpdesk support & 3.61 & Practiced \\
\hline Establish qualifications for positions. & 3.43 & Practiced \\
\hline Develops descriptions for positions. & 3.48 & Practiced \\
\hline Reviews and validates submitted content (periodical and on submitting new content) $\cdot$ & 3.45 & Practiced \\
\hline Monitors community activity by means of metrics * & 3.32 & Practiced \\
\hline Performs outreach of the community results. & 3.58 & Practiced \\
\hline Establish an organizational structure for programs. & 3.46 & Practiced \\
\hline $\begin{array}{l}\text { Spends time (staff, beneficiaries and stakeholders) reflecting on the success of the } \\
\text { project and learning for the future. }\end{array}$ & 3.28 & Practiced \\
\hline Defines responsibilities and authority of staff & 3.49 & Practiced \\
\hline AWM & $\mathbf{3 . 4 6}$ & Practiced \\
\hline
\end{tabular}

In terms of organizing, the management practices of community development activities generated an average weighted mean of 3.45 , expressed as practiced. All of the indicators were rated practiced. The data implies that the efforts of the respondents in organizing were just on the average level. From this result, it can be implied further that organizing needs to be strategized and strengthened so that the people composing the organization will sustain the project.

Table 5: Management Practices of Community Development Activities in terms of Leading

\begin{tabular}{|l|l|l|}
\hline Leading & WM & Description \\
\hline Selects qualified persons for available positions. & 3.87 & Highly Practiced \\
\hline Acquaints new persons with institution and program & 3.76 & Highly Practiced \\
\hline Supervises staff in performing new tasks & 3.68 & Highly Practiced \\
\hline Coordinates departmental activities & 3.82 & Highly Practiced \\
\hline Resolves differences among staff. & 3.62 & Highly Practiced \\
\hline Encourage creative efforts. & 3.42 & Practiced \\
\hline Leads people and activities. & 3.80 & Highly Practiced \\
\hline Adapts to change and innovation. & 3.64 & Highly Practiced \\
\hline Utilizes different ways to approach work problems. & 3.24 & Practiced \\
\hline $\begin{array}{l}\text { Develops a cooperative unit and the organization to achieve the optimal contribution of } \\
\text { all staff members. }\end{array}$ & 3.03 & Practiced \\
\hline Motivates staff towards achieving quality results. & 3.72 & Highly Practiced \\
\hline Contributes to delivery of public services. & 3.68 & Highly Practiced \\
\hline $\begin{array}{l}\text { Manages budget and finances within my unit and organization to achieve results within } \\
\text { available funding. }\end{array}$ & 3.83 & Highly Practiced \\
\hline $\begin{array}{l}\text { Establish relationships with stakeholders to assist in achieving the organization's goals } \\
\text { and objectives. }\end{array}$ & 3.83 & Highly Practiced \\
\hline AWM & $\mathbf{3 . 6 4}$ & Highly Practiced \\
\hline
\end{tabular}

In terms of leading, the management practices of community development activities tallied an average weighted mean of 3.64 perceived as highly practiced. Most of the indicators were rated highly practiced except for only three indicators which were noted as only practiced. As evidently shown, cooperation among members of the association or organization is greatly required to foster more unified efforts and raise the creativity towards established community development initiatives.

Table 6: Management Practices of Community Development Activities in terms of Controlling

\begin{tabular}{|l|l|l|}
\hline Controlling & WM & Description \\
\hline Develops evaluation criteria or standards & 2.82 & Practiced \\
\hline Assesses progress toward program objectives & 2.96 & Practiced \\
\hline Evaluates staff performance & 3.11 & Practiced \\
\hline Revises program plans based on evaluation & 2.98 & Practiced \\
\hline Coordinates necessary resources. & 3.14 & Practiced \\
\hline Assists with development of human resource plans. & 2.75 & Practiced \\
\hline Identifies and secures required facilities and equipment & 2.96 & Practiced \\
\hline Identifies and secures financial resources & 3.59 & Highly Practiced \\
\hline Identifies and secures program expertise and resources & 3.62 & Highly Practiced \\
\hline Monitors community transfer initiatives & 3.57 & Highly Practiced \\
\hline Evaluates community transfer initiatives & 2.32 & Practiced \\
\hline Provides accurate and timely reports to Council and to responsible agencies & 2.18 & Slightly Practiced \\
\hline
\end{tabular}




\begin{tabular}{|l|l|l|}
\hline There is good bookkeeping systems and financial reporting in place. & 2.27 & Slightly Practiced \\
\hline Has done evaluation of the project & 2.83 & Practiced \\
\hline Conducts mutual planning for tracking development of the activity. & 2.89 & Practiced \\
\hline Conducts Mutual planning for facility development for the activity. & 2.77 & Practiced \\
\hline AWM & $\mathbf{2 . 9 2}$ & Practiced \\
\hline
\end{tabular}

In terms of controlling, the management practices of community development activities garnered an average weighted mean of 2.92 known as practiced. From the given indicators, majority were found to be practiced which means only average. Meanwhile, only three indicators were highly practiced while the other two were slightly practiced. These results could certainly attribute that control within the association or organization has to be increased to chart echo-and-balance between available resources and their utility for production to stabilize community development activities. Moreover, the data suggests that, for control to be in place, proper reporting which includes financial aspect should be properly embraced and observed. This also implies that systematic reporting process and mechanism be used to make control a dynamic management function of the association or organization.

\subsection{Issues and Concerns in the Management of Community Development Activities}

Table 7: Issues and Concerns in the Management of Community Development Activities

\begin{tabular}{|lll|}
\hline Indicators & f & Rank \\
\hline Inadequate Skills & 190 & 2.5 \\
\hline Lack of funds & 193 & 1 \\
\hline Lack of time & 186 & 4 \\
\hline Improper management & 190 & 2.5 \\
\hline Political unrest & 75 & 6 \\
\hline Lack of partners & 83 & 5 \\
\hline Lack of information & 70 & 7 \\
\hline
\end{tabular}

*Multiple Responses

As projected in Table 11 on issues and concerns in the management of community development activities, lack of fund topped with a frequency of 193, followed by inadequate skills and improper management at second with frequencies of 190 for each. Ranked last is lack of information with a frequency of 70 . The data clearly depicts that funding is the greatest issue and concern in the management of community development activities. This result yields an implication that there is a need for funding for the association to be able to pursue community development activities. Likewise, there is also a need among the members of the association to possess the skills and management capabilities to achieve its goals and objectives.

\subsection{Five Year Plan on the Implementation of Community Development Activities}

Table 8: Five Year Plan on the Implementation of Community Development Activities

\begin{tabular}{|c|c|c|c|c|}
\hline Project/Activities & & $\begin{array}{l}\text { Length of } \\
\text { Project }\end{array}$ & & Budget \\
\hline Garbage Waste Disposal & $\begin{array}{l}\text { Intervention } \\
\text { /implementation }\end{array}$ & Year round & 15,500 & 500,000 \\
\hline Organize Livelihood Projects & Needs analysis & Year round & 14,300 & 436,000 \\
\hline $\begin{array}{l}\text { Sustaining and Safeguarding the } \\
\text { Environment }\end{array}$ & $\begin{array}{l}\text { Intervention } \\
\text { /implementation }\end{array}$ & Year round & 13,735 & 405,000 \\
\hline Cleanliness and Beautification & $\begin{array}{l}\text { Intervention } \\
\text { /implementation }\end{array}$ & Year round & 13,500 & 400,000 \\
\hline Health and Sanitation & Needs analysis & Year round & 13,000 & 425,000 \\
\hline Fiesta Celebration Activities & Technology design & 2 mos. & 12,600 & 100,000 \\
\hline Yuletide Season Activities & Technology design & 2 mos. & 10,000 & 100,000 \\
\hline $\begin{array}{l}\text { Fund Raising Activities of the } \\
\text { School/Church }\end{array}$ & Technology design & 3 mos. & 8,500 & 100,000 \\
\hline Family Mapping Activities & Technology design & 2 mos. & 15,000 & 75,000 \\
\hline $\begin{array}{l}\text { Barangay/Town } \\
\text { Celebrations/Commensuration/Annivers } \\
\text { ary Activities }\end{array}$ & Technology design & 2 mos. & 16,000 & 100,000 \\
\hline $\begin{array}{l}\text { Construction of Reading Centers in the } \\
\text { Barangay/Purok }\end{array}$ & Problem identification & $1 \mathrm{mo}$. & 13,400 & 500,000 \\
\hline Lenten Season Activities & Technology design & $1 \mathrm{mo}$. & 14,500 & \\
\hline $\begin{array}{l}\text { Solicitation/Collection of Donations for } \\
\text { Calamity Victims }\end{array}$ & Needs analysis & 2 mos. & 10,000 & 100,000 \\
\hline $\begin{array}{l}\text { Distribution of Relief } \\
\text { during/after calamities }\end{array}$ & $\begin{array}{l}\text { Intervention } \\
\text { /implementation }\end{array}$ & $\begin{array}{l}\text { When disaster } \\
\text { occurs }\end{array}$ & 15,000 & - \\
\hline Services Partners of NGO's & $\begin{array}{l}\text { Intervention } \\
\text { /implementation }\end{array}$ & $\begin{array}{l}\text { Occurrence of } \\
\text { disaster }\end{array}$ & 20,000 & - \\
\hline Health and Nutrition Program & Problem identification & 6 mos. & 17,000 & 500,000 \\
\hline
\end{tabular}


The above table displays the five year development plan of the community development activities of the association. This plan specifically covers projects/activities, length of project and budget. To be able to strengthen, expand and sustain the community development activities of the Parent-Teacher-Community Association, this plan has to be undertaken.

\section{Conclusion}

After thorough analysis of the results based on the findings gathered from the study, the researcher came up with a number of conclusions. The profile of the PTA stakeholders did not have much direct effect or influence on their management of community development activities of the association.Out of the four management functions exhibited by the PTA stakeholders, leading is what was well-practiced and where the association did very well.Finally, financial resources and competence of the stakeholders are necessary and highly needed for the successful operation and management of community development activities.

\section{Recommendation}

Based on the findings and conclusions of the study, the following recommendations are hereby offered for consideration: 1.) Capability building activities specifically on management should be undertaken in order to equip and enhance the knowledge, skill and competence of the PTA stakeholders; 2.) The school may hold seminar-workshops and training related to the core functions in management so as to train and strengthen PTA stakeholders to be able to perform effectively and efficiently particularly in planning, organizing and controlling; 3.) The PTA should look into their projects, programs and activities by prioritizing or venturing into something that provides or augments income for the association to survive as well as sustain its operation and existence; 4.) The PTA may find possible avenues to generate funding by forging linkages or partnership with charitable institutions, private agencies and other educational foundations that can support their projects, programs and activities; 5.) Similar studies maybe conducted but will examine other aspects and nature of variables on management skills and capabilities vis-à-vis community development related activities to come up with genuine and adequate data as basis for other future research into this subject.

\section{References}

[1] American Institutes for Research (AIR). (2008). New Schools Program: A final evaluation (Report to USAID). Washington, DC: Author.

[2] Bastiani, J. (1993). Parents as partners. In P. Munn (Ed.), Parents and schools: Customers, managers or partners (pp. 101-116). London: Routledge

[3] Becker, H. \& Epstein, J. L. (1982). Parent involvement: A survey of teacher practices. Elementary School Journal, 83, 85-102.

[4] Berger, E. H. (1995). Parents as partners in education. New York: Merrill.

[5] Chabbott, C. (2006). Community-Organized Primary Education (COPE) evaluation. Washington, DC: Unpublished.

[6] Carneal, C. C., \& Pozniak, M. (2004). Creating partnerships, educating children: Case studies from Catholic Relief Services. Baltimore: Catholic Relief Services.

[7] Chan, K. (1989). Linking school and home: parent-teacher association in Hong Kong secondary schools. Master of Education Dissertation. Hong Kong: The University of Hong Kong.

[8] Chavkin, N. (1989). Debunking the myth about minority parents. Educational Horizons, 67(4), 119-123.

[9] Chen, X., \& Chandler, K. (2001). Efforts by public K-8 schools to involve parents in children's education: Do school and parent reports agree? (NCES 2001-076). Washington, DC: US Department of Education. National Center for Educational Statistics. ED458256. http://nces.ed.gov/pubresearch/index.asp

[10] Cheung, C. K., Lam, C. M., \& Ngai, S. S. Y. (2008). Help from the parent-teacher association to parenting efficacy: Beyond social status and informal social capital. The Journal of Socio-Economics, 37, 1134-1152.

[11] Coleman, J. S. (1988). Social capital in the creation of human capital. American Journal of Sociology, 94, 95-120

[12] Davies, D. (2002). The 10th school revisited: Are school/family/community partnerships on the reform agenda now? Phi Delta Kappan, 83, 388-392.

[13] Hartwell, A. (1998). Enhancing girls' education through community schools. Washington, DC: Institute for International Research.

[14] Dauber, S. L., \& Epstein, J. L. (1993). Parents attitudes and practices of involvement in inner-city elementary and middle schools. In N. F. Chavkin (Ed.), Families and schools in a pluralistic society (pp. 53-71). Albany: State University of New York Press.

[15] Desimone, L. (1999). Linking parent involvement with student achievement: do race and income matter? Journal of Educational Research, 93, 11-30.

[16] Dornbusch, S. M., \& Ritter, P. L. (1988). Parents of high school students: A neglected resource. Educational Horizons, 66, 75-77.

[17] Dwyer, D. J., \& Hecht, J. B. (1992). Minimal parent involvement. The School Community Journal, 2(2), 53-66.

[18] Edwards, A., \& Warin, J. (1999). Parental involvement in raising the achievement of primary school pupils: why bothers? Oxford Review of Education, 25, 325-341

[19] Epstein, J. L. (1986). Parents' reactions to teacher practices of parent involvement. The Elementary School Journal, 86, 277-294.

[20] Ho, E. S. C. (1999). Parental involvement in children's education: the contribution of cultural and social capital. Education Journal, 26, 233-262.

[21] Sullivan-Owomoyela, J., \& Brannelly, L. (2009). Promoting participation: Community contributions to education in conflict settings. Paris, France: IIEP/UNESCO and CfBT.

[22] Donahue, J., \& Mwewa, L. (2006). Community action and the test of time: Learning from community experiences and perceptions; Case studies of mobilization and capacity building to benefit vulnerable children in Malawi and Zambia. Washington, DC: USAID.

[23] Education Commission (1997). Education Commission Report No. 7. Hong Kong: Government Printer. 
[24] Epstein, J. L. (1994). Theory to practice: School and family partnerships lead to 136 school improvement and student success. In C. L. Fagnano \& B. Z. Werber (Eds.), School, family, and community interaction: A view from the firing lines (pp. 39-52). Boulder, CO: Westview Press.

[25] Epstein, J. L. (1995). School-family-community partnerships: Caring for the children we share. Phi Delta Kappan, 76(9), 701-712.

[26] Fan, X. (2001). Parental involvement and students' academic achievement: A growth modeling analysis. The Journal of Experimental Education, 70(1), 27-61.

[27] Glasgow, N. A., \& Whitney, P. J. (2009). What successful schools do to involve families: 55 partnership strategies. Thousand Oaks, California: Corwin Press

[28] Gonzalez-DeHass, A. R., \& Willems, P. P. (2003). Examining the underutilization of parent involvement in the schools. The School Community Journal, 13, 85-99.

[29] Griffith, J. (1996). Relation of parental involvement, empowerment, and school traits to student academic performance. Journal of Educational Research, 90, 33-41.

[30] Grolnick, W. S., \& Slowiaczek, M. L. (1994). Parents' involvement in children's schooling: A multidimensional conceptualization and motivational model. Child Development, 64, 237-252.

[31] Grolnick, W. S., Benjet, C., Kurowski, C. O., \& Apostoleris, N. H. (1997). Predictors of parent involvement in children's schooling. Journal of Educational Psychology, 89, 538-548.

[32] Haar, C. K. (2002). The politics of the PTA. New Brunswick, N. Y.: Transaction Publishers

[33] Henderson, A. T. (1988). Parents are a school's best friends. Phi Delta Kappan, 70(2), 148-153.

[34] Ho, S. C. \& Willms, D. J. (2000). Effect of parental involvement on eighth-grade achievement. In E. J. Haller \& P. F. Kleine (Eds.), Using educational research: A school administrator's guide (pp. 315-332). Addison Wesley Longman, Inc.

[35] Ho, B. S. (2002). Application of participatory action research to family-school intervention. School Psychology Review, 31, 106121

[36] Hoover-Dempsey, K. V., Bassler, O. C., \& Brissie, J. S. (1992). Explorations in parent-school relations. The Journal of Educational Research, 85, 287-294.

[37] Izzo, C. V., Weissberg, R. P., Kasprow, W. J., \& Fendrich, M. (1999). A longitudinal assessment of teacher perceptions of parental involvement in children's education and school performance. American Journal of Community Psychology, 27, 817- 839

[38] Keith, T. Z., Keith, P. B., Quirk, K. J., Sperduto, J., Santillo, S., \& Killings, S. (1998). Longitudinal effects of parent involvement on high school grades: Similarities and differences across gender and ethnic groups. Journal of School Psychology, 36(5), 335-363.

[39] Knipprath, H. (2005). The role of parents and community in the education of the Japanese Child. Educational Research for Policy \& Practice, 3, 95-107.

[40] Ladd-Taylor, M. (1994). Mother-Work: Women, child welfare, and the state, 1890-1930. Champaign: University of Illinois Press.

[41] Lin, N. (2000). Social capital: Theory of structure and action. Cambridge: Cambridge University Press.

[42] Macbeth, A. (1993). Preconceptions about parents in education. In P. Munn (Ed.), Parent and schools: Customers, managers, or partners (pp. 27-46). London: Routledge.

[43] Mapp, K. L. (2003). Having their say: Parents describe why and how they are engaged in their children's learning. The School Community Journal, 13, 35-64.

[44] Inter-Agency Network for Education in Emergencies (INEE). (2003). INEE good practice guide: Community education committees. London: Author. Available at http://www.ineesite.org/toolkit/docs/doc_1_Community_Education_Committees.pdf

[45] Moles, O.C. (1993). Collaboration between schools and disadvantaged parents: Obstacles and openings. In N. F. Chavkin (Ed.), Families and schools in a pluralistic society (pp. 21-49). Albany: State University of New York

[46] Munn, P. (1993). Parents and schools: Customers, managers or partners. London: 142 Routledge. National Institute of Education (1985). Parent participation and the achievement of disadvantaged students. Washington, DC: ERIC Clearinghouse on Urban Education. (ERIC Document Reproduction Service No. ED 259040)

[47] National Institute of Education (1985). Parent participation and the achievement of disadvantaged students. Washington, DC: ERIC Clearinghouse on Urban Education. (ERIC Document Reproduction Service No. ED 259040) Nettles, S. M. (1991). Community involvement and disadvantaged students: A review. Review of Educational Research, 61(3), 379-406.

[48] Pang, I. W. (1997) Functions of the Parent-Teacher Association (PTA): A Hong Kong Perspective. Chinese University Education Journal, 25(1), 81-106.

[49] Parsons, T. (1959). The school class as a social system: Some of its functions in American society. Harvard Educational Review, 29, 297-318.

[50] Petr, C. G. (2003). Building family-school partnerships to improve student outcomes: a primer for educators. Lanham, Md.: Scarecrow Press

[51] Randell, M. (n.d.). Auditing community participation. Fremantle, Western Australia: Human Sciences.

[52] Rose, P. (2003). Communities, gender and education: Evidence from Sub-Saharan Africa; Background paper for UNESCO 2003 global monitoring report. East Sussex, England: University of Sussex, Centre for International Education.

[53] Rich, D. (1987). Teachers and parents: An adult-to-adult approach. Washington, DC: National Education Association

[54] Shartrand, A., Kreider, H., \& Erickson-Warfield, H. (1994). Preparing teachers to involve parents: A national survey of teacher education programs. Cambridge, MA: Harvard Family Research Project.

[55] Shaeffer, S. (1994). Participation for educational change: A synthesis of experience. Paris, France: IIEP/UNESCO.

[56] Shores, E. F. (1998). A call to action: Family involvement as a critical component of teacher education programs. Tallahassee, FL: South Eastern Regional Vision for Education.

[57] Schumann, D. (n.d.). Strategies that succeed: Stories from the SAGE project. Washington, DC: Academy for Educational Development. Available at www.aed.org

[58] Simon, B. S., \& Epstein, J. L. (2001). School, family, and community partnerships: 145 Linking theory to practice. In D. B. HiattMichael (Ed.), Promising practices for family involvement in schools (pp. 1-24). Greenwich, Conn.: Information Age Pub.

[59] Waller, W. (1932). The sociology of teaching. New York: Wiley.

[60] Weber, M. (1947). The theory of social and economic organization. New York: Oxford University Press. Wissbrun, D., \& Eckart, J. A. (1992). Hierarchy of parental involvement in schools. In L. Kaplan (Ed.), Education and the family (pp. 119-131). Boston: Allyn and Bacon.

[61] World Education Guinea. (2007). Community participation for equity \& quality in basic education in Guinea: Final report. Conakry, Guinea: World Education. 